\title{
O Orçamento-Programa no Brasil
}

\author{
J. Teixeira Machado Jr. \\ Técnico de Administração do BNDE e \\ Professor da FGV
}

SUMÁRIO: Introdução Histórica; Tipos de Orçamento; Problemas de Terminologia; Mensuração Fisica; Padrōes de Desempenho; A Prática Brasileira.

\section{INTRODUÇÃO HISTÓRICA}

O orçamento sempre foi considerado nos Governos, especialmente a partir do século XVII, o instrumento básico das finanças públicas. Para comprovar esta assertiva faz-se suficiente apenas compulsar o caudal de literatura que sobre o assunto surgiu na Europa continental, sobretudo na França e na Itália, mesmo que seja preciso reproduzir a tão conhecida citação de Gladston, segundo a qual o orçamento vai além da receita e da despesa para atingir a própria prosperidade dos reinos e dos povos, aqui resumida sem a presença do original.

Através do orçamento, coordenavam-se as despesas em funÇão das receitas, ou vice-versa, de acordo com a teoria política reinante em cada época, isto é, se no poder encontrava-se um Governo conservador para o qual o melhor orçamento é aquele que menos gasta ou se a preparação do orçamento estava nas mãos de um Governo soit-disant socializante, o qual pretendia minimizar as diferenças sociais com a arrecadação de pesados tributos. Surge desse embate a teoria das finanças compensatórias que, na verdade, domina hoje o complexo fazendário dos Governos modernos em qualquer país, resultante da observação de que a ação financeira dos Governos, por mais restrita que o seja, tem influência na economia nacional, podendo condicionar, na medida do grau de intervenção, a direção dos gastos dos cidadãos, quer individualmente, quer em coletividade. 
A evolução desta prática, com a criação de uma correspondente teoria, foi lenta até os primórdios do presente século, o que não impediu, no entanto, que se chegasse à refinada aplicação dos incentivos fiscais, última palavra das finanças compensatórias, através dos quais o Governo motiva os inversionistas e condiciona os investimentos para aplicação em setores prioritários ou na direção de regiões mais carentes, ao invés de deixar em mãos do setor privado maior quantidade de dinheiro cuja aplicação talvez fosse menos produtiva para a economia nacional.

No entanto, é provável que a primeira observação desse tipo tenha sido feita com a aplicação de impostos elevados a certos produtos considerados prejudiciais à saúde ou ao bem- estar dos cidadãos, pois é quase imemoriável a utilização dos impostos como meio coercitivo do uso ou da fabricação de certos produtos. Por outra, os Governos sempre se valeram dos tributos sobre artigos considerados de luxo - jóias, perfumes, bebidas alcoólicas, fumo e outros desse jaez - para canalizar recursos financeiros, permitindo, destarte, aliviar a tributação daquelas mercadorias ditas essenciais.

Sob o ângulo econômico, parece que a primazia pertence ao grande financista do século XVIII, Alexandre Hamilton o verdadeiro HOMEM DO SÉCULO - que obteve do I Congresso da nascente república dos Estados Unidos da América do Norte forte tributação alfandegária sobre os produtos industrializados da Europa. Tal política tributária condicionou a emigração de capitais ingleses, dos Países Baixos principalmente e, mesmo, da França, possibilitando, assim, fácil e barato financiamento para o impulso industrial que a América iria desenvolver nos anos vindouros até hoje, mormente porque tais capitais se nacionalizaram, não por força de lei, mas em função do lucro e do crescimento da economia daquela nação.

Parece que a história das finanças públicas, nos séculos XVII, XVIII e XIX, indica que a receita pública tem uma acendrada predominância nesta tentativa de condicionamento da economia, embora isto não signifique uma evolução nas técnicas orçamentárias, nem mesmo na composição estrutural do orça-
mento público.

Este condicionamento da receita não é, aliás, de modo nenhum de estranhar, pois toda a história financeira mostra que o interesse por este lado da equação orçamentária sempre sur-

R. Serv. Públ., Brasília, 108 (1): jan/abr. 1973 
giu em primeiro plano. Com efeito, na luta entre barões feudais da Grã-Bretanha e os soberanos pelo controle dos dinheiros públicos, a instituição da receita pública foi tratada com especial carinho e chegou-se mesmo ao ponto de não haver referência à despesa. Assim foi na Carta Magna, assinada por João-Sem-Terra, nos comecos do século XIII. Mesmo quando a luta se institucionalizou politicamente, com o definitivo estabelecimento do Parlamento, após a revolução que os ingleses chamam de gloriosa e que levou ao trono Guilherme de Orange e a Rainha Ana, a limitação do poder de lançar impostos e taxas, levantar empréstimos e obter donativos foi a arma que o Parlamento, em ascendente dominação política, encontrou seguindo a tradição da Idade Média, para consolidar também seu poder financeiro, evolução que se completaria nos começos do nosso século.

Ainda por muitos e muitos anos, a despesa seria vista tão-somente como o instrumento de pagar funcionários, comprar mercadorias, pagar as despesas de guerra ou, resumindo no jargão da Economia moderna, comprar bens e serviços. Somente muito mais adiante, na história da humanidade foi que a despesa começou a ser visualizada e compreendida como um instrumento de condicionamento econômico e social. Afigura-senos, todavia, que esta é uma propriedade inerente à despesa pública. De fato, quando, naqueles idos, reis, imperadores e déspotas jogavam seus povos em guerra, forçando a entrada de maiores recursos financeiros em suas arcas, estavam inconscientemente também, redistribuindo esses recursos em razão de compra de armamento, de víveres, de pagamento de soldos às tropas etc. Mesmo sem guerras, as obras públicas, por mais limitadas que fossem, bem como o tradicional pagamento de vencimentos ao funcionalismo e aos agregados ao trono já significavam um meio de retirar uma parcela do montante do dinheiro da coletividade para contemplar outros elementos dessa mesma coletividade e até de coletividades estrangeiras. Apenas, o processo não era sistematizado nem conscientizado. Tudo leva a crer, no entanto, que César, Imperador romano, na clarividência do pensamento latino, já possuía alguma consciência de que o Governo pode intervir decididamente nesse processo. Com efeito, Emil Ludwig, na biografia romanceada de Cleópatra, conta-nos que, ao voltar do Egito, verificou César que o populacho estava indócil com a falta de emprego, não podendo pagar pão e circo. Ordenou ele, então, a execução de grandes obras públicas para empregar a massa que, de outro 
modo, poderia vir a constituir perigo para a estabilidade da ordem interna de Roma. Como se vê, é inerente à despesa pública o princípio de que esta, de um modo ou de outro, condiciona a conjuntura econômica de um país. A magnitude deste condicionamento é mera questão de grau com que o Governo utiliza o segundo membro da equação orçamentária. Não só de grau, no entanto, mas também de conscientização e de racionalização do processo de intervenção.

Ao iniciar-se o presente século, a Grã-Bretanha - novamente a Ilha - apresentava-se no cenário internacional como uma nação dominadora dos mares, como um império onde o sol não se punha, para repetir o velho jargão. Entretanto, internamente a situação não se configurava das mais risonhas, pois a desigualdade de participação de todas as classes no produto nacional era flagrante, tanto assim que foi em Londres que Carlos Marx assentou seu laboratório para estudar e descrever a luta de classes e criar sua célebre teoria do materialismo histórico. Entre os últimos anos do século passado e os primeiros do corrente, reformou-se a lei eleitoral com extensão do direito de voto ao proletariado mais parcamente remunerado, suprimindo-se a exigência de uma renda básica para o exercício desse direito. Tal reforma proporcionou a eleição de um Parlamento dominado pelo Partido Liberal, o qual subiu ao poder com maioria esmagadora e dentre seus membros sobressaíram as figuras do Primeiro Ministro Asquith e do Chanceler do Erário, Lloyd George, o qual, posteriormente, faria, como Primeiro Ministro, a primeira Grande Guerra.

A Câmara dos Comuns, orientada por esses dois líderes, aprovou, pelos idos de 1909 , se não nos trai a memória, o que se poderia chamar com propriedade o primeiro orçamento intervencionista, já agora em um processo conscientizado, embora de sistemática imprecisa, porque lhe faltava o apoio de uma teoria que, somente com as publicações de Keynes, muitos anos depois, vem a surgir. No orçamento de Lloyd George, os impostos, sobretudo os diretos, foram elevados a um grau jamais concebido antes, de modo a canalizar um Amazonas de libras esterlinas para o erário de Sua Majestade. Ao mesmo tempo, a despesa pública foi condicionada dentro de uma programação econômica básica, de acordo com a filosofia política imperante no Partido Liberal, visando conscientemente ao favorecimento das universalmente chamadas classes menos favorecidas. 
Tudo indica, portanto, que cabe ao nosso século a primazia de ter proporcionado em seu decorrer a evolução do orçamento como um instrumento de orientação econômica e de trabalho dos Governos, iniciando, concomitantemente, a racionalização, nem sempre porém continuada, e a conscientização de utilizar o orçamento como meio de programação.

Não custa, já que tomamos o rumo da lição da história, assinalar que a aprovação do orçamento de Lloyd George não foi pacífica. De fato, os membros da Câmara dos Lordes, na suposição de que tal orçamento lhes afetaria os interesses privados por que seriam eles - como realmente o foram - os principais contribuintes para o fortalecimento das finanças compensatórias, negaram aprovação, devolvendo os originais à Câmara Baixa. Esta, porém, sob a inspiração daqueles dois estadistas, reagiu de modo inesperado talvez. Aprovou, então, projeto de lei retirando da Câmara Alta o poder de votar matéria financeira. Uma série de negociações políticas, envolvendo até - Rei e, sobretudo, a ameaça de nomeação de tantos Lordes, escolhidos do Partido Liberal, quantos fossem necessários para suplantar a maioria retrógrada da Câmara Alta, forçou esta a aprovar o projeto de lei de reforma e do orçamento. Assim é que, até hoje, a Câmara dos Lordes apenas conhece o orçamento e outras leis de finanças, mas não as discute nem vota. Desta forma foi que quando Mr. Attle, Primeiro Ministro do Partido Trabalhista, ao assumir o poder, depois da segunda guerra, pretendeu abolir a pena de morte na Grã-Bretanha e não encontrou apoio, mais uma vez, na Câmara dos Lordes, a imprensa inglesa aconselhou-o a suprimir do orçamento as dotações para compra de cordas, já que sobre tal assunto, estritamente financeiro, a Câmara dos Lordes é constitucionalmente impotente para legislar.

Este exemplo de seu próprio país teria possivelmente inspirado a Keynes os primórdios de sua teoria dos orçamentos correntes e de capital, a qual ajudou o mundo ocidental a vencer a grande crise dos últimos anos da década dos '20 e dos primeiros da dos ' 30 , com os indispensáveis burilamentos doutrinários de seu brilhante gênio.

O próximo exemplo que nos ocorre de utilização da despesa pública em seu papel de condicionante da conjuntura econômica de um país, já surge toda ela estritamente baseada na teoria keynesiana, ao referirmo-nos à experiência de Franklin 
Delano Roosevelt, no New Deal, causando imenso impacto positivo na adormecida economia norte-americana de 1932, quando aquele estadista assumiu o poder. Já agora o processo de utilizar a despesa pública como condicionante econômico é, não só querido, conscientizado, como extremamente racionalizado dentro da contextura de um planejamento básico estruturado no National Recovery Plan, fundamento da Administração rooseveltiana. Esse plano, no entanto, que a Suprema Corte julgaria posteriormente inconstitucional, motivou o aparecimento de uma farta literatura pró e contra o planejamento governamental. Mesmo eivado de inconstitucionalidade, o NRP produziu conseqüências duradouras na economia daquele país porque muitos de seus programas vieram a ser cumpridos, embora fora da contextura integral do plano, tal como a Lei do Seguro Social, em cuja apreciação a Suprema Corte reverteu sua posição anterior de considerar inconstitucional as leis aprovadas pelo Congresso originárias do NRP, talvez em face de pressões políticas incontroláveis. Realizou-se mesmo assim um imenso plano de obras públicas, até que a grande nação do norte se viu envolvida no conflito para debelar o flagelo do nazi-fascismo.

As conseqüências da ação da Administração Roosevelt para o orçamento público foram inúmeras e perduram até hoje, pois foi a partir dessa época, com a transferência do órgão de orçaçamento - The Bureau of the Budget - do Tesouro para ficar subordinado diretamente ao Presidente e com a orientação imprimida por Harold D. Smith, que se começou a pensar seriamente em técnica orçamentária. Foi ainda nessa mesma época que as empresas privadas daquele país começaram a vislumbrar no orçamento um instrumento de auxílio ao processo de racionalização e programação de suas operações e finanças. A consciência de racionalização despertada na empresa privada com os estudos de Fayol na França e de Taylor nos Estados Unidos encontrou no processo orçamentário uma ferramenta para condicionar a programação física com a programação financeira.

Conseqüentemente, a utilização consciente da despesa pública como instrumento de política econômica é fato muito recente na história da humanidade. Tal observação pode ser facilmente suportada pela opinião de vários autores, entre os quais destacamos a de Frederick C. Mosher, para quem "não foi senão muito recentemente, há cerca de duas décadas, que maior 
atenção se dirigiu para o lado da despesa do orçamento ou para a aplicação de princípios e técnicas econômicas à administração das finanças públicas." 1

\section{SURGIMENTO DO ORÇAMENTO-PROGRAMA}

É interessante notar que, nada obstante a imensa contribuição rooseveltiana para o desenvolvimento do aspecto técnico do orçamento público (já agora podemos identificar a dualidade: orçamento público e orçamento empresarial), não foị no Governo Federal dos Estados Unidos que se originou a idéia e se implantou a técnica do orçamento-programa, embora pessoas insuficientemente informadas façam tal assertiva em função dos trabalhos das duas Comissões do Congresso norte-americano, liderados pelo ex-presidente Hoover, cujos relatórios sobre finanças públicas aconselharam a introdução, no Poder Executivo, de um orçamento que, por falta de melhor denominação (sic), a primeira Comissão passou a chamar de performance-budget, cedo traduzido em língua portuguesa por orçamento funcional, no sentido de que esse tipo de orçamento deveria exprimir (como bem diz a expressão em inglês) as realizações governamentais. A palavra função adquiriu, então, sinonímia com a palavra setor de ação governamental. Na realidade, a idéia básica da I Comissão Hoover dirigia-se para um orçamento-deexecução, segundo o qual um produto final surgiria no final dos trabalhos.

Na verdade e nada obstante a grande contribuição de Harold D. Smith como Diretor do orçamento federal norte-americano por vários anos, especialmente durante o período da guerra, quando pessoalmente assumiu grandes encargos, Smith jamais praticou, aconselhou ou mesmo falou em orçamento-programa. Basta para tanto consultar, além dos orçamentos preparados sob sua direção, o. livro The Management of Your Government 2 por ele escrito, meio esquecido hoje, mas ainda cheio de ensinamentos. Não nos olvidamos, contudo, de que, ao analisar os princípios orçamentários, Smith erigiu como um deles a propriedade de o orçamento adaptar-se aos objetivos fundamentais da entidade para a qual é elaborado. Assim, não concebia ele que o orçamento de uma estrada de ferro, pelo simples fato

1. Mosher, Frederich C., Program-Budgeting: Theory and Practice. (Public Administration Service: Chicago, 1954), pág. 2. O autor se situa estritamente na economia americana, sem aprofundar a análise histórica internacional.

2. Smith, Harold D., The Management of Your Government. (New York: Whittlesey House, McGraw-Hill Book Company, 1945). 
de ser operado por uma empresa pública, tivesse a mesma estrutura de um orçamento ministerial. É provável que Smith, com a evolução de seu pensamento, teria deixado valiosa contribuição para o desenvolvimento do orçamento-programa, se não tivesse desaparecido tão cedo e, pois, tivesse podido continuar seu trabalho de orçamentista mesmo em outro plano que não o federal.

É óbvio, pelo menos para nós outros que olhamos o orçamento mais como um instrumento de ligação da programação física - para torná-la exeqüível - com a programação financeira, que o Governo Local - o Município - apresenta maiores e melhores condições para o surgimento e desenvolvimento desta técnica. E foi isto exatamente o que aconteceu. Pelo menos os registros históricos nos informam que foi em uma pequena cidade do Estado de Nova York, denominada Richmond, como a capital da Virgínia, que nasceu e implantou-se o orçamento por programas.

Realmente, é no Governo Local, sobretudo com a concepção que dele se tem nos Estados Unidos, eminentemente de prestação de serviços à comunidade, que surge a necessidade de programar a ação governamental, ultrapassando-se o tipo de orçamento em que se discriminam os meios, basicamente de natureza legal, para outro em que, primeiramente, se identificam os problemas da comunidade e, em seguida, equacionam-se esses problemas em termos de meios necessários, fundamentalmente um orçamento programático, no momento exato em que a humanidade começa a caminhar de um Estado regulador para um Estado executor, sem, todavia, abdicar de suas funções anteriores. Quanto ao surgimento do orçamento-programa nos Governos Locais norte-americanos com prioridade ao Governo Federal, trata-se, pelo menos, da lição que nos ensinam os meIhores tratadistas de orçamento daquele país, entre os quais destacamos Jesse Burkhead, em seu já clássico Government Budgeting, felizmente já agora circulando no Brasil em tradução em língua portuguesa, graças aos esforços da Fundação Getúlio Vargas. ${ }^{3}$ É verdade, por outro lado, que a demarragem do processo de orçamentação à base de programas em larga escala deve-se, sem dúvida, às recomendações das duas Comissões Hoover, já referidas.

3. Burkhead, Jesse, Government Budgeting. (Nova York: John Wiley and Sons, Inc., 1956).

R. Serv. Públ., Brasilia, 108 (1): jan/abr. 1973 
Não foi nossa intenção fazer restrições à obra de Harold D. Smith ao apontar a gênese do orçamento-programa nos Governos Locais. Temos plena consciência do valor desse técnico, falecido prematuramente, pouco depois de deixar, já na Administração Truman, a direção do Bureau do Orçamento e de escrever o livro já citado. Entre outras contribuições de Smith vale, de passagem, assinalar sua preocupação de entrosar o Bureau de Orçamento com as Universidades, levando a estas a palavra dos técnicos do Bureau e trazendo destas o ensina mento dos professores universitários, em benefício de uma sa. lutar corrente de pensamento e de troca de idéias de que re. sultou farta literatura em língua inglesa à disposição dos estudiosos. Smith, igualmente, sempre pensou que orçamento e organização e métodos deveriam caminhar juntos, embora, na prática, surgissem algumas dificuldades ao melhor entrosamento das duas técnicas. Vemos hoje o renascer dessa filosofia, como prova o fato de o Bureau do Orçamento do Governo norte-americano ter passado a denominar-se, talvez pela pressão do BPPS ${ }^{4}$ The Office of the Budget and Management. De outro lado, não é próprio, outrossim, ignorar a profunda análise que as duas Comissões Hoover procederam no Poder Executivo do Governo Federal norte-americano, em nome do Congresso, com peso preponderante para o desenvolvimento da idéia do orçamento-programa, cuja análise da prática brasileira nos propomos a fazer na segunda parte deste trabalho. Pareceu-nos, contudo, de importância traçar um panorama, ainda que de horizontes amplos, da gênese desta técnica de administração moderna. ${ }^{5}$

\section{TIPOS DE ORÇAMENTOS}

Parece-nos, no entanto, de proveito antes de enfocar o caso brasileiro, aclarar diferenças entre certos tipos de orçamento, os quais foram surgindo no processo administrativo, mas tiveram, como é natural, suas práticas descontinuadas à medida que outros mais sofisticados surgiram. Não é nossa intenção, com isto, porém, pretender demonstrar que um tipo de orçamento é menos ou mais eficiente que outro, nem nos move a

4. PBBS, em inglês: Planning, Programing, Budgeting System. Um sistema desenvolvido por MacNamara, no Departamento de Defesa norte-americano, segundo o qual se integram em uma linha contínua, o planejamento, a programação $e$, sua expressăo financeira, o orçamento. Por isto mesmo, em português temos preferido chamar de Sistema Integrado de Planejamento, Programaçăo e Orçamento, SIPPO.

5. Aparentemente, este trabalho dá pouca relevância à contribuiçăo da França e da Itália para o desenvolvimento do orçamento público pela simples razăo de que a preocupaçăo predominante do pensamento francês e italiano sempre se voltou para o aspecto jurídico do orçamento público. 
idéia de elevar o orçamento-programa a pedestal de panacéia capaz de resolver todos os males administrativos. Já existe hoje plena consciência de que não é o tipo de orçamento que resolve os problemas da administração pública, mas o modo como um dado tipo de orçamento é operado pode ser ainda mais importante. Apenas é de reconhecer-se que, ao passo que os Governos se vão tornando responsáveis pela demarragem e orientação do processo desenvolvimentista, o orçamentoprograma aparece, sem dúvida, como instrumento de trabalho mais apropriado, mais preciso, mais técnico e que melhor condiciona a programação física à programação financeira.

Afigura-se óbvio que o processo financeiro existe desde que a humanidade se constituiu em Estado, pois um dos condicionantes desta instituição é o seu poder de exigir dos súditos contribuição em moeda para manter os serviços governamentais. Estaria fora do escopo deste trabalho seguir tal linha de pensamento, de vez que a história das Finanças Públicas trata com minúcias da evolução do poder de tributar outorgado aos Governos. É fato notório, por outro lado, que, enquanto as finanças existem desde tempos imemoriais, a programação física do complexo de operações governamentais só recentemente apareceu como um imperativo categórico para racionalização dessas mesmas operações e obtenção de maiores resultados com menor dispêndio de recursos financeiros. Está fora de cogitação, porém, a imensa utilidade do orçamento-programa como a melhor técnica para expressão dos planos físicos, em termos de moeda e para controle físico e financeiro, sobretudo nesta conjuntura em que se continua a tradição dos recursos escassos e em que os Governos assumem responsabilidade pelo estudo e equacionamento na busca de solução dos mais graves problemas nacionais em horizontes temporais amplíssimos. Vejamos, preliminarmente, os principais tipos de orçamento.

Orçamento tradicional, muito conhecido com o nome de lei de meios. Contempla os meios de que o Governo pode dispor em um exercício financeiro para conduzir a administração sem qualquer relação, porém, com os problemas a enfrentar, vale dizer, sem a coordenação programática.

Orçamento econômico. Não chega a ser um orçamentoprograma, mas visa sobretudo a considerar a economia nacional como um conjunto integrado, procurando infletir a ação governamental para aqueles setores pelos quais a iniciativa 
privada mostra menor interesse. Assim, fala-se em orçamento econômico nacional, e, por via de conseqüência, em balanço econômico nacional, mas não há como confundir este com o orçamento econômico do Governo, parcela do orçamento econômico do setor público que, por sua vez, constitui uma parte do orçamento econômico nacional, sendo, portanto, um instrumento de intervenção estatal. A Finlândia chega ao ponto de fazer aprovar pelo Parlamento, não só o orçamento governamental, mas também o próprio orçamento econômico nacional que, destarte, se torna lei. Uma das características deste tipo de orçamento é que condiciona meios a grandes problemas nacionais, tornando-se, às vezes, de difícil implementação a nível estadual e municipal, pois que sua destinação é de natureza macro-econômica.

A doutrina keynesiana, que levou ao orçamento econômico, produziu, no Brasil, a Lei $4.320 / 64$, por alguns considerada, embora a nosso ver impropriamente, a lei de orçamento-programa. Este pensamento emana da observação de que a Lei 4.320/64 dividiu as operações governamentais em correntes e de capital, como categorias essenciais para a programação governamental. Mas, no instante em que a aplicação e a interpretação da lei especialmente com o controle dos Tribunais de Contas da União e dos Estados sobre as finanças municipais passaram para os juristas, por formação profissional mais preocupados com o controle que com a programação, desenvolveu-se a idéia de dois grupos dicotômicos aparentemente estanques: receitas e despesas correntes, de um lado e receitas e despesas de capital, de outro, como se o orçamento não fosse uma integridade programática. Deste modo, a classificação da receita passou a condicionar a da despesa, perdendo o orçamento a flexibilidade necessária para ser um verdadeiro instrumento do planejamento em termos monetários. É verdade que o próprio fato de a lei separar, tanto na receita como na despesa, as transferências em correntes e de capital poderia parecer exata a dicotomia extremamente estanque acima referida. Levada a este rigor, nenhuma esfera de Governo poderia contrair um empréstimo para saldar um compromisso classificável em despesas correntes, de vez que as operações de créditos classificadas na lei como receitas de capital só em despesas de capital poderiam ser aplicadas. Tal dicotomia fechada cria problemas enormes, mormente para as Prefeituras municipais, sobrecarregadas com encargos ditos correntes, mas da maior magnitude para a vida do Município, como entre outras a manutenção do ensino. 
Neste ciclo fechado, uma Prefeitura não poderia vender bens inserviveis para desenvolver o ensino como, por exemplo, contratar novos professores ou pagar melhores salários. $O$ ativo do balanço patrimonial poderia abundar de bens inúteis para a Prefeitura, mas esta não teria condições de aliená-los para atender a encargos com o ensino, a saúde, limpeza pública, etc. mantida a dicotomia legal ao exagero, como, lamentavelmente, alguns juristas pretendem.

Daí decorre outra observação importante. De fato, com a Lei $n .^{\circ} 4.320 / 64$ desenvolveu-se também o conceito - ou preconceito - de que as despesas, correntes são, social e economicamente, menos valiosas que as despesas de capital, pois que estas de modo genérico se transformam em bens de capital, como tal contabilmente registráveis no ativo governamental. Este é um dos defeitos do chamado orçamento econômico, em relação ao orçamento-programa, ao descaracterizar os serviços prestados pelo Governo, para ressaltar a ênfase com a criação de bens de capital, como se fosse socialmente útil construir uma escola, um hospital, ou comprar um equipamento e não fazê-los funcionar. O orçamento-programa elimina tal distorção, porque coloca a ênfase no programa a executar, no objetivo a atingir, na meta a completar, desde que sua natureza tenha sido previamente determinada como imprescindivel à coletividade, exigindo que, ao cabo do exercício financeiro ou do período de tempo esquematizado, surja um produto final, característica fundamental do orçamento-programa. Este produto final pode ser um prédio escolar, um ambulatório, mas pode ser, da mesma forma, o número de alunos que concluiram a terceira série do curso primário nas escolas do Município. ${ }^{6}$

O estudioso pode identificar outros exageros de classificação, facilmente encontradiços na Lei $4.320 / 64$ à medida que a mesma pretendeu estabelecer um orçamento econômico para as três esferas do Governo de nosso sistema federativo. Por exemplo, a diferenciação entre investimentos e inversões financeiras e entre alguns títulos dessas duas categorias. Assim, um terreno adquirido para nele ser construído um prédio é um

6. É com satisfaçåo que podemos, a esta altura do pensamento do planejamento ofi. cial, vislumbrar modificaçăo substancial nestes conceitos com reversão para a clas. sificaçåo por projetos e atividades, enfatizando com maior precisão os objetivos e metas perseguidos em termos de eficácia e de beneficios à coletividade, em substituição aos conceitos de investimentos e custeios, já que as próprias Naçōes Unidas de custeio sảo fazer desenvolvimento só com investimentos e que muitas despesas R. Serv. Públ., Brasília, 108 (1): jan/abr. 1973 
investimento, mas a aquisição de um prédio já pronto uma inversão financeira. A entrada no ativo de ações do Banco do Brasil é uma inversão financeira, mas da Petrobrás é um inyestimento, dadas as características comerciais e industriais prepoderantes de cada uma dessas empresas de econorima mista. É provável que, sob o prisma estritamente econômico, todo este sistema de classificação seja muito importante, mas, por outro lado, a lei não toma em consideração o objetivo a atingir e daíraro corre-se o perigo de preparar e executar um orçamento simplesmente para identificar categorias econômicas e não para realizar um produto final em benefício das populações. Para o administrador, o importante é que a escola seja construída e os alunos recebam instrução, ou que uma ponte ligando duas margens de um rio dê passagem a pessoas e mercadorias, construida com material novo ou não. O mais importante é o objetivo e não o meio ou a categoria econômica em que se classifique o meio utilizado. Daí a relevância do orçamento-programa, por equacionar meios em função de objetivos e daí porque, também, discordamos, data venia, de que a Lei $4.320 / 64$ seja uma lei de orçamento-programa, embora achemos que ela não impede a implementação desta técnica no Brasil e, bem interpretada, sem exageros legalísticos, até que ajuda, especialmente no desenvolvimento de um tipo de controle positivo e não meramente punitivo. Controle positivo é aquele controle que motiva, incita, vocaciona as bases administrativas para a realização eficiente de sua missão, visando ao cumprimento integral do produto final. Fixa o rumo de ação como a bússola indica o rumo do navio e mostra, assim de logo, os problemas que vão surgindo na execução, os quais são debatidos sem preocupação com a hierarquia funcional, mas com a ênfase colocada na busca de solução, de modo que o objetivo e a meta se completem no tempo previsto com as especificações projetadas, partindo-se dai para a administração por exceção.

Incidentemente, há uma riqueza de conceituação em denominar-se orçamenta a este processo. Orçamentar é fixar rumo, segundo os dicionários, que fazem prevalente na nomenclatura náutica e originário do italiano ou do neerlandês. Na palavra orçamento vive maior expressão de força que na palavra inglesa budget, passada para o francês (le budget) de onde, aliás, veio originariamente (bougette) ou para o alemão (das budget) ou na palavra espanhola presupuesto. 
A continuação, a distinção acima já apontada de transferências correntes e de capital, é outro exagero que não se justifica mesmo em razão da teoria do orçamento nacional, pois na consolidação das contas as transferências se anulam, fazendo-se a agregação ao nivel em que as despesas são efetivamente apropriadas a um objetivo específico, além de, como já vimos, jungir a aplicação dos recursos financeiros à sua origem.

Quanto à despesa, é possível, por exemplo, notar a classificação de salário-familia, abono familiar, juros de dívida pública e diferença de câmbio, na categoria das transferências.

Com efeito, presidiu a idéia de apropriar à categoria das transferências salário-família e abono familiar o fato de que tais adicionais ao salário do servidor decorrem, não do serviço por ele diretamente prestado, mas em razão do número de dependentes que oneram seu orçamento particular em auxílio do qual o Estado the proporciona um adicional. Ora, é claro que se o Estado pagasse um salário tal que não fosse necessário conceder benesses adicionais, o custo total do salário seria, indiscutivelmente, apropriado ao programa, ou à unidade administrativa a que o servidor serve. Há tempos nossa atenção já tinha sido advertida para o fato de os orçamentos dos Governos Central da França e Federal dos Estados Unidos da América do Norte não comportarem tal distinção, levando diretamente ao custeio dos serviços todas as despesas sobre os mesmos incidentes, coisa, aliás, que sempre nos pareceu racional que a sofisticação de levar tais contas à categoria das transferências correntes. De fato, o Governo não transfere a nenhuma entidade, nem a pessoas, a responsabilidade pela realização de um serviço ou produção de bem, os quais - realização e produção estão sob direta administração estatal, cujo custo se acresce destas benesses. Quando o Governo compra os serviços pessoais, está naturalmente e ex lege, também se comprometendo a pagar tais adicionais. Além de um erro conceitual, tal classificação, excessivamente especializada, concorre para aumentar inutilmente o trabalho de elaboração e controle dos orçamentos públicos.

Por seu turno, porém, a conta contribuição de previdência social, que significa a parte do empregador para o fundo previdenciário, constitui um caso flagrante de prestação indireta e mediata de serviço, pois a dotação constante do orçamento se destina a comprar o serviço do INPS, do IPASE ou de outra instiR. Serv. Públ., Brasilic, 108 (1): jan/abr. 1973 
tuição seguradora, para futura prestação financeira ou assistencial, não mais ao Governo, porém a pessoas, os aposentados.

Caso aberrante, no entanto, é de juros da dívida pública, pois estes representam um custo financeiro, direto e imediato, do empréstimo. Veja-se o Manual para Classificação das Transações do Governo segundo seu Caráter Econômico e sua Função, editado pelo Departamento de Assuntos Econômicos e Sociais das Nações Unidas em 1959, do qual consultamos o original em língua espanhola. De fato, ali encontramos à página $147 \mathrm{ni}$ tidamente distinguidos em títulos diferentes:

- Gastos líquidos correntes em bens e serviços

- Juros pagos no governo central

- Juros

- Pagamentos diretos de subvenções

- Transferências à conta de receita de unidades familiares

- Transferência ao governo local para operações correntes

- Transferências correntes ao exterior.

No mesmo sentido é o plano geral, às páginas 93 a 95, que comentamos no livro Classificação das Contas Públicas, editado pela Fundação Getúlio Vargas, em 1967.

Como se vê, um manual excelentemente técnico não considera os juros como transferência, nem podia fazê-lo sob pena de incidir em erro. O fato é que a Lei $4.320 / 64$ esqueceu-se dos custos financeiros das transações governamentais, e, pois, seu plano de contas deveria comportar distinção de, pelo menos, dois tipos de custeio:

- custeio em bens e serviços

- custeio financeiro, ou outros títulos mais convenientes, nunca, porém, considerar como transferência um custo direto de empréstimo, certamente oneroso para a administração. Um título como custeio financeiro teria ainda a vantagem de agrupar, com propriedade, outras contas como despesas de exercícios anteriores, alguma outra dotação especial para tipos de dividas a liquidar ou amortizar, bem como diferença de câmbio, pois que esta última conta se nos afigura com todos os característicos de um custeio financeiro, da mesma forma que juros da divida pública. Transferência é que, certamente, não nos parece que o seja, pois o câmbio é remetido para compra de bens e serviços e a diferença adere ao principal. 
Como se vê, classificar contas, sob o ângulo da racionalidade do orçamento, não é tão simples como pode parecer à primeira vista. É imprescindível aprofundar a análise para encontrar a substância da transação, pois que, de modo geral, o que se classifica não é a conta, mero instrumento de representação, mas as próprias transações. E, conseqüentemente, preciso descer, ou subir, até estas para encontrar sua verdadeira posição no conjunto geral das operações governamentais. Esta foi, aliás, a mensagem que procuramos transmitir no livro já citado, Classificação das Contas Públicas.

Por sua vez, a dívida pública outra coisa não é senão baixa de passivo à semelhança de restos a pagar. Deve-se então classificar a amortização da dívida pública como uma transferência? A resposta se nos afigura ser negativa, porque o Governo não transfere a outra entidade a responsabilidade de prestação de serviço nem a realização de obras, apenas paga o que deve. Como classificar, pois, a amortização da divida pública? A nosso entendimento, trata-se de uma baixa direta do passivo, contabilizável no exercício em que ocorre a amortização, sem incidência em categoria econômica específica.

Não se poderá, jamais, determinar o exato custo dos serviços públicos se as despesas não apresentarem classificação que lhes precisem exatamente seu papel como fatores determinantes de custo.

A transferência aparece quando o Governo entrega dotação a outra entidade, de direito público ou privado, para que ela execute um serviço ou realize uma obra, de interesse coletivo, que o próprio Estado (sentido lato) poderia executar, mas, por razões de política administrativa ou econômica, prefere delegar atribuições e recursos. Não é, parece-nos, o caso das contas acima discutidas, mas seria, certamente, o caso de bolsas de estudo, por que o Estado em vez de prover diretamente o ensino, paga a entidades privadas ou públicas para
fazê-lo.

Aliás, a definição da Lei $4.320 / 64$ para as despesas de transferências está perfeitamente em compasso com o raciocínio que expusemos acima, de delegação de atribuições e dotações, ou, mais acertadamente, nosso raciocínio paralela a defi-
nição da lei.

R. Serv. Públ., Brasília, 108 (1): jan/abr. 1973 
A nosso parecer, o plano de contas contido no Anexo n. 4 , em consonância com o artigo 13 da lei $4.320 / 64$ é que, na realidade, desviou-se do conceito emitido pelo $\S 2 .^{\circ}$ do artigo 12, de transcrição:

"Classificam-se como Transferências Correntes as dotações para despesas às quais não corresponde contraprestação direta em bens ou serviços, inclusive para contribuições e subvenções destinadas a atender à manutenção de outras entidades de direito público ou privado."

Destarte, as transferências são essencialmente as subvenções sociais, as subvenções econômicas, os auxílios e as contribuições, para utilizar a mesma terminologia, da mencionada lei, desde que a contraprestação em bens e serviços não seja direta ao Governo. Ora, nos casos anteriores, a prestação de serviços é direta e imediata, onerando os custos dos respectivos serviços.

Observe-se, para encerrar este assunto, a inadequação da redação do $\S 6 .^{\circ}$ do mesmo artiga 12 , que, ao definir as Transferências de Capital, considerou-as independente de contraprestação direta em bens e serviços, por isto que tais dotações estão vinculadas a investimentos ou inversões financeiras. De qualquer maneira, porém, a frase é perigosa porque pode levar à presunção de que ficaria facultado a um Governo transferir recursos sem a competente prestação, ainda que não direta ou imediata, em bens ou serviços, tanto mais quanto o referido parágrafo não perderia sentido se tal frase fosse omitida, mas, ao contrário, ganharia concisão.

Orçamento Plurianual de Investimento. Uma das boas idéias surgidas com o orçamento econômico foi, sem dúvida, a da programação a longo ou médio prazos, resultando, no Brasil, por força do Decreto-lei 200/67, a institucionalização do ORÇAMENTO PLURIANUAL DE INVESTIMENTO - OPI, posteriormente consagrado na Constituição ex vi parágrafo único do artigo 60 e terceiro do artigo 62, com a regulamentação dos Atos Complementares de $n .{ }^{\circ}$ s 43/69, 76/69 e 9/70. Desta forma a implementação do orçamento-programa em nossa terra já vem favorecida com a institucionalização da programação a longo, médio e curto prazos, que lhe é necessariamente inerente. 
Por outro lado, na escala de valores da despesa pública, tem-se atribuído relevância aos investimentos como já referimos anteriormente, mas, na abrangência do orçamento-programa, tal escala de valores há de ser revista, pois está fora da técnica do orçamento-programa a concepção de que uma categoria de despesa seja superior a outra, de vez que a importância primordial recai no objetivo a atingir, ou, em outras palavras, o objetivo é que define a importância da despesa. A partir deste raciocínio, o orçamento plurianual de investimento sofreu uma extensão salutar, para incluir também as chamadas despesas correntes, tornando-se a antiga sigla OPI em ORÇAMENTO PLURIANUAL INTEGRADO, isto é, compreendendo para o período de tempo determinado por lei, no Brasil três anos, tanto as despesas de capital como as correntes. Destarte, o OPI torna-se a base em que se assentará o orçamento-programa de execução
anual.

A programação, como o processo orçamentário, há de ser contínua e sistemática, sem o que não se pode pensar em aperfeiçoamento nem mesmo em exatidão da programação empreendida. A continuidade significa que, a cada exercício, as dotações contidas no último ano do OPI, à vista de cuidadosa revisão para colocá-las em consonância com a conjuntura vigente, passam para o orçamento anual, verdadeiro executor dos planos contidos no OPI. Um pouco além disto, porém. É imprescindivel a análise permanente para que o ano do OPI que se extrapola para o orçamento de execução seja substituido por outro ano mais além, de modo que se mantenha a integridade do triênio ou outro prazo fixado para preparação do OPI, desse modo, na verdade, a programação se estende por um período de quatro anos: o do exercício (E), no orçamento em execução; e três anos seguintes $(E+1, E+2, E+3)$ compreendidos no OPI.

De acordo com as idéias expostas quanto aos dois tipos de orçamento, parece-nos claro que os orçamentos de inves timentos do Governo do Prof. Carvalho Pinto, em São Paulo foram muito mais orcamento ex-Presidente Juscelino Kubitschek foram muito mais orçamentos econômicos que orçamentos-protração estadual nem a fagem, que, à época, nem a adminisseus orçamentos econômicosal se preocupou em especificar programa de execução anual. 
Orçamento funcional. Institucionalizado pela primeira Comissão Hoover, este tipo de orçamento procura identificar, em primeiro lugar, as funções em que o Governo deve empregar os recursos financeiros. Aí, ao invés de salientar as despesas com pessoal, com aquisição de bens e serviços $€$, ao invés de salientar a categoria econômica em que incide urna despesa governamental, o orçamento funcional, ou orçamento por funções, procura mostrar o que o Governo faz ou pretende fazer. Por isto, o esforço total do Governo aparece dividido em funções (veja-se no Manual de Orçamento por Programa e Atividades, publicação das Nações Unidas, tradução em língua portuguesa sob os auspicios do Ministro Reis Veloso, do Planejamento, a definição completa de funções) ${ }^{7}$ que outra corrente de pensamento prefere chamar de setores. Assim, pode-se saber quanto dos recursos financeiros do Governo está sendo aplicado em educação, saúde, industrialização, transporte, comunicações, defesa nacional, segurança de pessoas e bens, urbanização, comércio, cultura, administração geral, agricultura, pecuária, bem-estar social, administração especifica etc. ${ }^{8}$

A determinação de quantas funções deve ter um Governo é certamente problema a ser resolvido na prática, em consonância com a magnitude de ação do mesmo. Geralmente, costuma-se dividir as funcoōes em subfunções e estas em programas, subprogramas, atividades e subatividades.

Desenvolvimento econômico, ou desenvolvimento econômico e social, não é evidentemente uma função ou setor, mas o grande objetivo nacional.

A agregação das responsabilidades governamentais no Brasil em dez títulos, incluindo a administração geral e destacando a administração financeira, foi a orientação seguida pelo Decreto-lei $n .{ }^{\circ} 2.416$, de 17 de julho de 1940 . A mesma orientação aderiu a Lei $4.320 / 64$, com as modificações posteriores introduzidas pelo Ministério do Planejamento e Coordenação Geral, à medida que o Governo da União, a partir de 1965, iniciou um processo sistemático de implementação do orçamento-programa a nivel federal.

7. Para comentários doutrinários a respeito do conceito de funções, o leitor é convidado a consultar de nossa autoria o livro Classificação das Contas Públicas (Rio de Janeiro: Fundaçăo Getúlio Vargas, 1967).

8. Em realidade, como já dissemos, a I Comissăo Hoover estava mais interessada em realizações e execução que em funçōes, parecendo-nos este título verdadeira re. duçåo de conceitos. 
Tudo leva a crer que a primeira recomendação para implementação das técnicas do orçamento funcional, da União, tenha sido feita pela CEPA ${ }^{9}$, em cujo relatório sobre finanças públicas aparece uma neste sentido, sem, no entanto, indicar os passos necessários, na presunção, perfeitamente aceitável, de que, pela tecnicidade da matéria, os detalhes de implantação deveriam ser objeto de estudo mais acurado por um Grupo de Trabalho constituido de pessoas versadas no assunto. O Governo cujo mandato se iniciou a janeiro de 1961 não tomou conhecimento do trabalho da CEPA e os sucessivos relatórios sobre reformas administrativas, de 1961 a 1964, foram suplantados pelas crises politicas que convulsionaram o país.

Já exprimimos o pensamento, em artigo publicado na Revista de Administração Pública, da Fundação Getúlio Vargas, de que a idéia do orçamento funcional não prosperou, no Brasil, à falta de sólida teoria que desse apoio à prática que se ia desenvolvendo a nível estadual e municipal, de vez que a União ficava fora das normas do Decreto-lei 2.416/40. Parece-nos que todos os demais fatores determinantes do atraso brasileiro em orçamento-funcional, nada obstante a existência de um instrumento legal consignante de funções definidas, são apenas conseqüências desta falta, isto é, de uma teoria que acompanhasse o desenvolvimento da prática e, em sentido contrário, comunicasse à prática que melhoramentos, ano após ano, deveriam ser introduzidos.

Alguns dos fatores colaterais que impediram, por tantos anos, o aperfeiçoamento da prática do sistema instituido pelo Decreto-lei 2.416/40, foram: a inexistência da conscientização de que se tratava de um orçamento funcional, tanto que este próprio nome só aparece muitos anos depois; a idéia prevalente, até bem pouco tempo, de que o orçamento deveria servir, essencialmente, para obtenção de dados estatísticos e para controle, mais propriamente que para a programação; o fato de que a condução do processo orçamentário nos Estados e Municipios brasileiros sempre esteve a cargo de contadores, geralmente, por formação profissional, mais afeitos à idéia de controle que à de programação; o fato de que o órgão que deveria dar assistência técnica a Estados e Municípios não teve, até sua recente extinção, condições, por motivos que fogem à nossa

9. Comissăo de Estudos e Projetos Administrativos, CEPA. Relatório final sobre normas para elaboraçăo, execução e controle orçamentário (Departamento de Imprensa
Nacional, 1961).

R. Serv. Públ., Brasilia, 108 (1): jan/abr. 1973 
percepção, de aparelhar-se convenientemente para teorizar a concepção contida no Decreto-lei n. ${ }^{\circ} 2.416 / 60$ e na Lei $4.320 / 64$ e proporcionar uma vasta rede de treinamento específico, deixando, portanto, de dar cumprimento integral à sua missão; falta de troca de informações entre Estados e Municípios, por inexistência de um centro coordenador que deveria ter sido o próprio órgão acima referido, sobre a condução de seus negócios orçamentários; ${ }^{10}$ a idéia de que o orçamento seria basicamente uma parte do processo contábil, idéia esta que está em relação direta com a condução dos orçamentos por contadores sem treinamento específico para esta especialidade; a ausência de coordenação administrativa entre o órgão central do orçamento (geralmente o contador) e os responsáveis pela condução das atividades-fim, como os diretores de departamento de educação, saúde, obras públicas, urbanismo, etc. Enquanto o primeiro administrava o orçamento dentro da premissa, quase insultuosa, do "não tem verba", os outros exageravam nos pedidos de verbas (estamos de propósito utilizando a nomenclatura anterior), já na expectativa de que seus pedidos seriam podados com uma tesoura extremamente afiada. Tal situação, na administração orçamentária brasileira, tornou-se tão aguda que proporcionou mesmo o surgimento de conflitos pessoais entre o responsável pelo órgão central de orçamento e os responsáveis pela atividade-fim, sem culpa real de um ou de outros, pois a ambos faltava o necessário treinamento e a percepção de que vivemos em uma economia de recursos escassos e de que o orçamento é a peça para condicionar tais recursos à solução das necessidades coletivas. No entanto, mais que um problema técnico, identificam-se, nessas lutas pessoais, problemas de coordenação administrativa e de relações humanas no trabalho, não privativas do Brasil, porém. Com efeito, Frederick C. Mosher identifica problemas de competição na administração orçamentária dos Estados Unidos não só entre o órgão de orçamento e entre os diversos responsáveis pelas atividades-fim, mas também entre esses. ${ }^{11}$ Temos aí um problema da chamada lei das reações antecipadas e cuja solução não cabe, com exclusividade, à área da administração orçamentária.

10. O Ministério do Planejamento e Coordenaçăo Geral supre, hoje, esta falha.

11. Mosher, Frederick, C., op. cit. págs. 41 e seguintes. Destaque-se a frase bem representativa do problema: "Each administrator is competing with his associates for his shares of the "pie", and the pie is usually not big enough to go around". Ou esta outra: "And not least among the qualifications of an administrator and a budget officer are their abilities as tacticians and gladiators in the budget process". (págs. 15 e 16, respectivamente) 
Como já transparece nas linhas acima, outro fator de preponderância substancial, embora aqui por pura questão metodológica colocado em último lugar, apresenta-se na ausência de um racional sistema de elaboração orçamentária, em que as necessidades públicas sejam convenientemente mensuradas a termos de moeda e de unidades de serviço a prestar ou de obra a executar, com preliminar e indispensável definição e clarificação dos objetivos a atingir, técnica que somente surge com a doutrina do orçamento-programa.

A teoria que desejariamos se apoiasse na prática e, em um processo de retro-informação, contribuísse para melhoria da prática, desenvolveu-se nos Estados Unidos com a colaboração, como já salientamos, entre o Bureau de Orçamento e as Universidades, ao passo que estas e as próprias Escolas de Comércio, no Brasil, sempre se abstiveram de estudar o orçamento como técnica específica, coisa que só se passou a fazer, em nosso país, com o surgimento da Escola Brasileira de Administração Pública, da Fundação Getúlio Vargas. A disciplina foi, então, proficientemente lecionada pelo emérito Professor Sebastião Sant'Anna e Silva, cujos cursos freqüentamos em 1954 e a quem, embora imerecidamente, tivemos a honra de substituir de 1957 a 1968. Coube também a Sant'Anna e Silva a primazia de aperfeiçoar, a nível federal, o orçamento público, com a introdução de classificação mais objetiva para a despesa, mas sua rápida passagem como Diretor da Divisão de Orçamento, do antigo DASP, não permitiu a desejada evolução.

Um orçamento funcional não se caracteriza, porém, apenas pela existência de um sistema de classificação da despesa por funções. Inerente à idéia de orçamento funcional está o conceito de custo dos serviços públicos. Aliás, a Comissão Hoover pretendia um custo líquido, segundo o qual das despesas que formariam o complexo do custo de uma função deveria ser de. duzida, se fosse o caso, a receita advinda com a venda de bens e serviços produzidos pela função. Isto mostraria, exatamente, qual a participação das dotações orçamentárias no financiamento de tais funções. A idéia de custo não esteve presente no Decreto-lei 2.416 , nem se encontra na Lei $4.320 / 64$.

O resultado mais flagrante da listagem prévia de funções foi a confusão criada, e ainda hoje reinante, em muitos Governos de nosso sistema federativo, entre função e departamentalização. Na realidade, as funções nada mais eram e, em alguns R. Serc. Públ., Brasilia, 108 (1): jan/abr. 1973 
casos ainda hoje são, senão meras reproduções, na estrutura orçamentária, da estrutura de organização, impedindo, assim, o desenvolvimento programático e de custo, mas, sem dúvida alguma, facilitando elementarmente a elaboração das propostas orçamentárias.

Vale a pena assinalar que o interesse do Governo Federal, e pois sua ação, projeta-se de modo mais realístico e específico. Não se fala mais em orçamento funcional. Sabe-se exatamente que o aperfeiçoamento dos orçamentos públicos no Brasil deve seguir a trilha do orçamento-programa, segundo o qual não só se especificam funções ou setores, como, também, fixam-se objetivos que podem ultrapassar um ou mais exercícios financeiros, medem-se metas a serem cumpridas anualmente, estabelecem-se prioridades, identificam-se os centros de decisão, relacionam-se os elementos humanos e os meios materiais disponiveis ou que possam tornar-se disponiveis, e estudam-se os recursos financeiros necessários para a aquisição desses elementos e desses meios, de modo a formular uma matriz econômica entre metas e recursos, pois qualquer que seja o tipo de orçamento, este só poderá exercer bem seu papel quando cobre as seguintes características, que resumimos de J. Meyer: 12

1. ser uma atribuição de objetivos e meios;

2. representar um equilibrio macro-econômico;

3. exprimir uma atribuição de responsabilidade;

4. possibilitar ligação constante com a evolução econômica;

5. ser, em resumo, um modelo econômico.

Como se depreenderá, o orçamento-programa pode mais facilmente preencher todas estas características, mas, voltamos ao orçamento funcional para dizer que uma preocupação dos técnicos com sua implantação, a qual se estende também ao orçamento-programa, no que tange à determinação de custos, reside na decisão sobre se o custo total das atividades estritamente administrativas devem ou não ser rateados entre as atividades-fim. Uma decisão desse tipo, porém, só na prática poderá ser tomada, em razão dos equipamentos mecânicos ou eletrônicos e dos recursos humanos disponíveis para uma opera-

12. Meyer, J: Gestion Budgetaire (Paris: Casa Dunod, 1966) pág. 10. 
ção exata e que não eleve em demasia os custos administrativos.

Na medida em que, como já assinalado, a classificação funcional não parou na função ou na subfunção, desdobrando-se estas em atividades, subatividade e tarefa, criou-se certa confusão com o orçamento-programa porque este utiliza igual terminologia. Por muito tempo, pensou-se que orçamento funcional e orçamento-programa fossem uma só e única técnica, cabendo a Jesse Burkhead, mais uma vez, na obra já citada, dirimir a dúvida a este respeito, mostrando a autonomia de cada um destes tipos.

Orçamento-Programa. Na definição de Jesse Burkhead, o orçamento-programa é aquele tipo de orçamento que

"apresenta os propósitos, objetivos e metas para os quais a Administração solicita as dotações necessárias, identifica os custos dos programas propostos para alcançar tais objetivos e dados quantitativos que medem as realizações e o esforço realizado em cada programa." 13

A leitura da definição já nos mostra algumas peculiaridades do orçamento-programa que o distingue dos demais tipos, mesmo do orçamento funcional, que foi, por assim dizer, a primeira etapa na evolução que conduziu à integração do sistema de programação física com as finanças públicas.

Primeiro, não se trata, tão-só, de identificar funções e apropriar meios às mesmas, mas dentro dessas estabelecer propósitos, ainda que gerais, tendendo para uma especificidade maior que na função, por sua natureza essencialmente genérica, ao passo que um propósito já significa que o administrador pretende algo determinado dentro da função. Para exemplificar com o federalismo brasileiro, poderíamos dizer que o propósito do Governo Federal no campo da educação é mais amplo que o propósito de um Governo Municipal, embora ambos estejam atuando dentro da mesma função. Poder-se-ia até, dentro deste canal de raciocínio e partindo da estrutura a ser levantada de um orçamento-programa nacional, chegar à repartição de atribuições entre as três esferas de Governo que passariam a atuar coordenadamente dentro do federalismo cooperativo de-

13. Burkhead, Jesse, op. cit., pâg. 142.

R. Serv. Públ., Brasília, 108 (1): jan/abr. 1973 
senvolvido no Brasil de alguns anos a esta parte. Tal repartição de atribuições evitaria a invasão dos campos de atuação de cada esfera de Governo, a pulverização de recursos, e a duplicação ou triplicação de esforços dentro do mesmo setor. Enquanto, v.g., o Governo Federal planejaria o sistema educacional e cultural do país e operaria as Universidades de ensino superior, os Estados-membro teriam sua ação concentrada no ensino de grau médio e o Município desenvolveria o ensino primário. Este é um meio de distribuir os propósitos dentro dessa função, mas, não necessariamente o único, pois se poderia conceber outro sistema em que houvesse delegação de atribuições perfeitamente coordenada. ${ }^{14}$ É óbvio que, ao mencionar a educação e cultura, estamos tomando a função mais simples de raciocinar para colocar o problema apenas em caráter exemplificativo. Com efeito, o orçamento-programa, dentre suas vantagens, apresenta a de identificar superposições de atribuições, mas, por outro lado, não cabe necessariamente ao técnico de orçamento resolver tais problemas quando levantados na elaboração orçamentária. A identificação e colocação de um problema desta natureza pode ser do técnico de orçamento, mas a solução há de ser pesquisada pelo conjunto das pessoas dedicadas ao estudo e à prática das atividades-fim. Em outras palavras, a atribuição de propósitos dentro de uma função deverá caber aos especialistas com a indispensável colaboração do técnico de orçamento.

Já notamos que estrutura de programas não se confunde com estrutura de organização e, à medida que o orçamento-programa força o emprego de análise crítica dos problemas, exigindo pensamento e ação, força necessariamente remodelação completa do conceito de estrutura de organização, pois o importante é o produto a obter e não a chefia a que se deve obediência.

\section{PROBLEMAS DE TERMINOLOGIA}

Os tratadistas têm desenvolvido uma terminologia não fácil às vêzes de conceituar, porque nas técnicas, nem sempre, as palavras mantêm o mesmo significado que lhes atribuem os dicionários. É possível que propósito, objetivo e meta sejam de algum modo sinônimos. Na técnica orçamentária cumpre porém distinguir.

14. Sobre o assunto de repartiçăo de atribuiçŏes, veja-se: Lordello Ne Melo, Diogo, o Municipio na Organizaçăo Nacional (Rio de Janeiro: IBA.M, 1971). 
Ao pensar em objetivo, já estamos penetrando tecnicamente em um campo mais restrito em que se formula um ponto preciso para atingir. A idéia de objetivo em orçamento-programa já introduz à coordenada de tempo. O propósito pode ser tão amplo que tenha vida perene, não limitada no tempo, mas o objetivo, por seu turno. pressupõe não só o espaço, União, Estados, Municípios, mas o tempo durante o qual se vão processar as tarefas para chegar-se ao objetivo. Dotar o Estado de uma rede de estabelecimentos de ensino secundário em cinco anos, já é um objetivo que atende a um propósito fixado dentro da função educação e cultura. Dotar o Município de uma biblioteca pública, com a construção ou aquisição de um prédio adequado e fornecimento de livros, de modo que, em dois anos já se disponha de 1.000 volumes, é outro objetivo que paralela o propósito fixado dentro do mesmo setor.

Ao pensar em termos estritamente técnicos, parece-nos certa a idéia de que o objetivo deve estar ligado a um processo de orçamentação plurianual ao passo que a meta deve ser a quantificação do objetivo no orçamento-programa anual. Facilmente, porém, pode-se verificar que é possível quantificar o objetivo mesmo no orçamento-programa plurianual. De fato, o objetivo já mencionado de dotar o Estado de uma rede de prédios escolares em cinco anos pode perfeitamente ser quantificada em um orçamento-programa plurianual. É, apenas, uma questão de os técnicos de ensino, os engenheiros e os orçamentistas chegarem a um acordo para definir uma unidade que deva medir a meta: metros quadrados de construção? salas de aula? que outra? Assim, como a unidade escolhida pode servir para elaborar o orçamento anual, deve servir, da mesma forma, para a elaboração do orçamento-programa plurianual.

No nosso modo de pensar, portanto, a meta é a quantificação, a um horizonte de largo, médio ou curto prazo, do objetivo e este, por sua vez, especifica um propósito dentro de uma

Entretanto, por mais técnica e prática que seja a concepção do orçamento-programa, o administrador está visceralmente vinculado a pensar, também, em meios. Por isto a definição acima, além de enfatizar a concepção do orçamento-pro-

15. Nosso pensamento tem evoluido para ligar objetivo a programa e meta a projeto ou atividade. Mera escolha, mas com propósitos de ordem prática.

R. Serv. Públ., Brasília, 108 (1): jan/abr. 1973 
grama como instrumento de fixação e quantificação de metas, refere-se às dotações necessárias para cumprimento dos mesmos. Surge dai o princípio de que o orçamento-programa é abrangente; integral. Enquanto que o orçamento tradicional apenas se preocupava com os meios, a nova técnica integra a variável meio aos objetivos e metas. Desta forma, o administrador não pode deixar de preocupar-se com os primeiros ao pretender introduzir em sua azzienda a técnica do orçamento-programa. Ademais, o problema dos meios passa a ser enfocado, não só em seu aspecto financeiro, mas em termos de recursos humanos e materiais, embora a importância dos recursos financeiros seja de tal monta que nem houvesse necessidade de uma referência aos mesmos, dado que esta variável está intrinsecamente ligada à idéia de orçamento. De qualquer modo, parece-nos importante mencionar que, na técnica do orçamento-programa, a preocupação do administrador ou do orçamentista deve alargar-se para pensar em razão de recursos humanos e materiais de que se serve a administração para cumprir suas metas. Por exemplo, em uma região madeireira, uma construção de madeira pode ser menos onerosa e mais rápida que utilizando cimento, areia, tijolos, etc., ainda que esses materiais não sejam escassos. Às vezes, ao contrário, é a raridade ou inexistência de um meio que obriga 0 administrador a valer-se de outro e isto tem influência na elaboração de um orçamento. Como vemos, o orçamento-programa leva forçosamente o administrador a preocupar-se tanto com programas como com meios para implementação dos primeiros. É por isto que se faz necessário, no processo de orçamentação, levantar um rol dos meios disponíveis e para maior facilidade classificá-los em elementos humanos, recursos materiais, energéticos, institucionais e de outras espécies.

A monetarização desses recursos é o que, a grosso modo, poderiamos denominar de dotação orçamentária. Na verdade, no sistema orçamentário brasileiro alguns termos têm sido empregados sem definição apropriada, o que tem concorrido para a dispersão dos conceitos terminológicos com prejuizo do entendimento geral. A Constituição do Brasil, e.g., fala em "transposição, sem prévia autorização legal, de recursos de uma dotação orçamentária para outra" (alinea a) do artigo 61). Que é dotação? qual a distinção entre dotação e crédito orçamentário referido mais adiante na alínea d) do mesmo artigo? tal distinção pode ser muito clara para um técnico do Ministério do Planejamento ou para uma pessoa mais versada no assunto, mas não será sempre assim; além disto, não se trata só desses 
dois termos nem de que o conhecimento seja personalizado, mas institucionalizado. É sobretudo quando começamos a pensar em controle orçamentário positivo que se verifica a imprecisão terminológica. Com efeito, a nomenclatura do orçamento tradicional permeia, na prática brasileira, a técnica do orçamento-programa, com prejuízo da conceituação, tanto mais quanto certos termos, utilizados abundantemente no processo orçamentário nacional, não foram até hoje objeto de uma conceituação técnica cuidadosa, pelo menos para uniformizar o entendimento da linguagem em todos os rincões do país. Temos, de certo modo, nos colocado em posição diversa à padronização de contas, especialmente à medida que evoluímos na implementação do orçamento-programa, por isto que este é, como já sabemos, um instrumento de identificação de problemas a resolver, os quais, por sua vez, são essencialmente diversos em cada região do território nacional e entre as três esferas de Governo. Tal posição, no entanto, não obsta a compreensão de que, certas contas, particularmente as que exprimem meios ou por sua generalidade são, não só padronizáveis como necessariamente se impõem a quem quer que deva elaborar um orçamento. Quanto à nomenclatura, porém, achamos imprescindivel sua uniformidade, único meio de possibilitar um entendimento a nível nacional, desejável até mesmo a âmbito internacional, como sucede com as ciências e técnicas de teorias consolidadas.

\section{MENSURAÇÃO FÍSICA}

Custos formam outro elemento da definição de orçamento-programa. Isto impõe, por via de conseqüência, estudo cuidadoso da composição da despesa de cada programa.

A idéia de custo está inseparável da idéia de benefício que a ação governamental deve levar às comunidades, especialmente em paises que lutam para vencer o subdesenvolvimento. Como os recursos monetários do setor governamental são basicamente obtidos, nos Estados modernos, através do mecanis mo da tributação, é imprescindivel que os Governos, a qualquer nível, se preocupem com a economia e a eficiência da manejados pelos Governos última análise, os recursos financeiros do setor privado. Há, pois, inúmeras razõetários transferidos devem permear a técnica do orçeras razões por que os custos modernos, democraticamente preocuto-programa nos Governos nheiro arrecadado do público, preocupados em outorgar, com diR. Serv. Públ Brasilia, 108 .un jontar. 
à maioria dos cidadãos. Há, destarte, uma imediata relação custo/benefício que, em futuro próximo, dará a base de toda a estrutura de análise orçamentária. A determinação do benefício está intrinsecamente ligada à fixação de objetivos e impõe uma análise relativamente complexa, vez que pode haver multidões de fatores com influência no benefício resultante da despesa pública. A literatura sobre o assunto é escassa, mas pode-se consultar algumas obras em inglês, além de alguns artigos publicados em revistas especializadas. ${ }^{16}$

Não menos complexo, no entanto, é o problema da determinação de custos nos Governos, não só pelo caráter político deste como porque o assunto tem sido negligenciado desde tempos imemoriais. Tem-se, por certo, contudo, que a implantação de um sistema de contabilidade de custos só será possível à medida em que as despesas públicas não cresçam com este novo serviço. Por isto mesmo, os estudiosos do orçamento-programa têm procurado desenvolver outras técnicas, com o auxílio da Estatística, capazes de dar, pelo menos, orientação básica em matéria de custo àquelas pessoas que formam os principais centros de decisão em cada esfera de Governo, como veremos a grandes traços a seguir, em consonância com o último elemento da definição que vimos analisando no decorrer destas páginas.

Trata-se, precisamente, de quantificar os dados que possam medir as realizações (benefícios) e o esforço despendido em cada programa. Cria-se, então, um sistema de mensuração das operações governamentais em termos físicos, como, aliás, já estabelecido na Lei $4.320 / 64$, no parágrafo único do artigo 79 , in verbis:

"Esse controle" (do cumprimento do programa de trabalho, expresso em termos monetários e em termos de realização de obras e prestação de serviços) "far-se-á, quando for o caso, em termos de unidades de medidas, previamente estabelecidas para cada atividade."

O objetivo central de um sistema de mensuração física das transações governamentais é o de exprimir em unidade conven-

16. A Análise de Sistema na Racionalizaçăo do Orçamento: Ministério da Economia e Finanças da França, Revista de Administraçăo Municipal n. $0^{\circ} 100$, Ano XVII, Mai.-Jun., 1970, pág. 51/80, traduçăo de J. Teixeira Machado e A Análise de Custo-Benefício no Orçamento-Programa: Ibidem, n.0 105, mar.-abr., 1971, Ano XVIII, pág. 33/47. 
cional, como as do sistema métrico decimal (SMD), ou de outra natureza, a carga de trabalho a realizar, de modo que a elaboração orçamentária seja feita, não só em função da moeda, mas, também, da meta devidamente quantificada. É claro que um sistema deste porte permite controle da execução do orçamento com muito maior racionalidade, por isto que possibilita à Administração conhecer a fração efetivamente concluída da carga de trabalho programada e o custo incorrido, podendo-se mesmo chegar a dois tipos de custo:

custo prospectivo, isto, é, aquele calculado na fase de elaboração e com o qual a administração pensa realizar as obras e obter os serviços;

custo efetivo, ou seja, o custo final, realmente obtido ao encerramento do exercício ou na conclusão da obra ou no término do serviço.

A comparação entre os dois custos poderá, sem dúvida, fornecer ao processo de elaboração orçamentária um padrão de alto valor para comparação das propostas parciais das diversas unidades administrativas de um Governo e uma base para cotejar a eficiência e a economia das ações do Governo em relação às do setor privado da economia nacional. ${ }^{17}$

Além do acompanhamento ou controle financeiro, o sistema de mensuração das realizações em termos físicos por meio de unidades de trabalho permite o acompanhamento e o controle do plano de trabalho estabelecido para o exercício.

Como a verdade é boa conselheira, devemos dizer que a experiência brasileira de orçamento-programa não alcançou ainda este estágio, nada obstante o esforço ultimamente realizado. Tivemos notícia de que a Secretaria de Orçamento e Finanças (SOF) do Ministério do Planejamento iria executar estudo, a grandes dimensões, neste sentido, a que se teria denominado "Projeto SOF", mas, realmente, parece que até o findar o exercício de 1971 tal projeto ainda não fora iniciado. ${ }^{18} \mathrm{~A}$ Secretaria de Educação e Cultura do Governo Estadual do Rio Grande do Sul, trabalhando em colaboração com o órgão de orçamento do Estado, este, então, sob a direção do Prof. Guilherme Moogen,

17. Mosher, op. cit., pág. 5 e 6 .

18. Este esforço de mensuraçăo está sendo agora conduzido no programa de modernizaçăo administrativa liderado pelo MINIPLAN através da SEMOR. 
primeiro, ao que parece, a escrever em seu livro Orçamento Brasileiro ${ }^{19}$ sobre orçamento-programa no Brasil, produziu sistema racional de mensuração das atividades educacionais do Estado, mas, ao que nos consta, não evoluiu ainda para a determinação de qualquer tipo de custo.

Não é, também, de argüir-se que homem/hora seja unidade de mensuração de objetivos e metas, como se vê em alguns orçamentos brasileiros. Os próprios nomes já definem elementos de trabalho e não objetivos ou metas. Com efeito, homens ou, generalizando, pessoas, constituem um dos ingredientes de trabalho, dentro da coordenada do tempo, para obtenção do objetivo ou cumprimento da meta. Veja-se bem: não há uma crítica ao fato de um orçamento utilizar a medida composta homem/hora para compor seu orçamento; o que pretendemos deixar claro é que esta unidade mede elementos de trabalho e não objetivo. Deste modo, teremos dois conjuntos distintos, mas integrados, de unidades:

\section{Primeiro conjunto}

Unidade de objetivos para programas: área a reflorestar, e.g.

Unidade de meta para projetos ou atividades: árvore a plantar, v.g.

\section{Segundo conjunto}

Unidade de elemento humano envolvido no trabalho: homem ou pessoa

Unidade de tempo, durante o qual se processa o trabalho: ano, mês, dia, hora ou outra que for escolhida;

Unidade de ingredientes: saca ou quilo de cimento, e assim por diante, conforme o ingrediente que for empregado; neste campo, geralmente, não há grandes dificuldades.

Unidade Monetária: cruzeiro.

Unidade de energia: $\mathrm{kv} / \mathrm{h}$.

A relação entre a quantidade (conjunto de unidades) de objetivo a cumprir ou cumprida e a de homem/hora a utilizar ou utilizada, para continuar com a mesma unidade anterior, mostrará a eficácia da execução do programa e, por sua vez, a re-

19. Moogen, Guilherme, Orçamento Brasileiro.

R. Serv. Públ., Brasilia, 108 (1): jan/abr. 1973 
lação entre a quantidade de meta e de homem/hora indica a produtividade da execução do projeto ou da atividade. A utilização da unidade monetária, expressão das dotações respectivas, converte tudo isto em custo unitário, como explicado anteriormente.

As dificuldades, a nível de Governo Federal, para implantação de sistema de mensuração que sirva à elaboração e ao controle financeiro e físico do orçamento estão hoje grandemente minimizadas graças à possibilidade de utilização de sistema de teleprocessamento, a partir, v.g., da experiência do INPS e, deste modo, uma rede de telex ligada a um sistema de processamento eletrônico de dados poderia ser a chave para a solução do problema, permitindo ao Governo conhecer realmente e a tempo útil a execução financeira e de planos.

Outro problema importantíssimo conectado com o acima evidencia-se na necessidade de que os relatórios produzidos no sistema de controle sejam submetidos à análise conscienciosa para que deles a Administração extraia resultados que The possam orientar na condução dos negócios governamentais. Não se trata tão-só de apuração de irregularidades. O sistema deve ser de tal modo que tenha capacidade de evitar as irregularidades, não tanto pela coação, mas, sobretudo, pela orientação positiva, no sentido de que os responsáveis por atividades e projetos encontrem apoio na Administração superior e possam cumprir com exação seus programas de trabalho. Ai reside a diferença entre o controle legal, essencialmente punitivo e o controle administrativo ou político, verdadeira bússola para manter o responsável no caminho exato.

É de importância, ainda, salientar que um sistema de mensuração do tipo imaginado pela teoria do orçamento-programa aumenta a racionalidade do processo orçamentário como um todo, eliminando, de vez, aquela velha técnica de elaborar o orçamento na base de mais $10 \%$ ou mais $20 \%$, sem definição e mensuração de objetivos e fixação de metas devidamente quantificadas, abolindo, por via de conseqüência, o tradicional sistema de cortes indiscriminados, resultante necessária de pedidos também indiscriminados ou, em última análise, de falta de técnica precisa na elaboração do orçamento público. ${ }^{20}$

20. Um exemplo simples de mensuração de atividades administrativas, ainda nåo, porém, condicionadas ao processo orçamentário, pode ser encontrado na Revista

R. Serv. Públ., Brasília, 108 (1): jan/abr. 1973 
É-nos imperioso, todavia, deixar patente que sistema desta natureza tem esbarrado na dificuldade de estabelecer unidades de trabalho, como geralmente se vem denominando na literatura universal as unidades adequadas a medir a carga iniciále trabalho e o produto final, resultante da ação administrativa sér bre a primeira. ${ }^{21}$

\section{PADRÕES DE DESEMPENHQ}

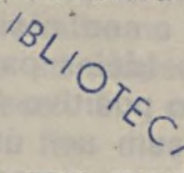

Se partirmos da hipótese de que é possivé, com aperføi çoamentos sucessivos, estabelecer um sistema de mensunęóa física - através das unidades de trabalho - para as transações governamentais, poder-se-á, então, criar determinados padrões de desempenho, entre os quais o mais simples é o que descrevemos no livro Gerência Financeira de Serviços d'Água, com simplificação introduzida no Modelo de Orçamento-Programa para Municípios, editados ambos pelo Instituto Brasileiro de Administração Municipal, sendo que o segundo sob os auspícios do Ministério do Planejamento e Coordenação Geral.

No primeiro trabalho, seguindo a linha geral de pensamento que vem regendo a doutrina do orçamento-programa, principalmente na literatura e práticas norte-americanas, bem como do Manual de Orçamento-Programa editado pelas Nações Unidas, a comparação se estabeleceu entre as realizações, ou produto final, e o esforço produzido para alcançá-las. Observe-se que quando se fala em realizações ou produto final, não se trata de olvidar a carga de trabalho inicial, mas, apenas, por uma simplificação, fundimos duas expressões em uma só: realizações esperadas ou produto final esperado e realizações obtidas ou produto final obtido. No segundo, com a simplificação introduzida para facilitar o trabalho a nível municipal e como primeira aproximação à solução do problema, estabeleceu-se a comparação entre as realizações e o montante das dotações em dinheiro. Embora na primeira solução forçosamente se chegue a monetarizar os resultados físicos, como explicado no mencionado livro, a segunda solução produz, de imediato, um custo unitário aproximado que pode perfeitamente ser utilizado para fins orçamentários, tanto na fase de elaboração como na de controle, sem embargo de que a primeira solução apresente características de maior tecnicidade, no que respeita à doutrina do orçamento-programa.

21. Work unit em inglês e unité d'oeuvre em francês.

R. Serv. Públ., Brasilia, 108 (1): jan/abr. 1973 
A implementação e conseqüente aperfeiçoamento de um sistema de mensuração, nos moldes indicados ou outro que venha a ser concebido, e somente assim, será a base para possibilitar ao órgão central de orçamento de um Governo desenvolver padrões para análise das propostas parciais e para melhorar, ano a ano, o sistema orçamentário do país, como um todo. Algumas idéias para criação de um sistema de controle orçamentário positivo à base de unidades de trabalho e de padrões que possam ser úteis em todo o processo do orçamento público, podem ser encontradas na Revista de Administração Municipal, n. ${ }^{\circ}$ 107, Ano XVIII, 1971, págs. 5/21.

As dificuldades estão mais do lado das realizações que do esforço, ou seja, dos elementos de trabalho. Com efeito, há certos produtos da administração cuja mensuração se torna difícil, como o trabalho puramente administrativo. Fácil é verificar que, nem sempre, o trabalho da administração apresenta homogeneidade bastante para ser medido por uma única unidade, a menos que se estabeleça simplificação muito grande que pode vir a ser, no entanto, perigosa. Um Agente Fiscal de Tributos pode passar três dias examinando a escrita de um contribuinte, ao passo que outro pode resolver, em um contribuinte diverso, todas as questões em algumas horas, com igual eficácia para o serviço público. Que unidade, então, se estabeleceria para mensurar tal atividade? A visita? O parecer ou o relatório produzido? Ao implantar-se um sistema de mensuração, portanto, algumas decisões pragmáticas deverão ser tomadas para que o sistema possa funcionar, introduzindo-se-lhe aperfeiçoamentos no decorrer dos anos, pois que sem esforço, sacrifício mesmo, sem tentativas, sem análise crítica, nada se alcança em administração.

Esta dificuldade não é privativa da unidade de trabalho, aplicada à atividade puramente administrativa, tal como se compreende em orçamento-programa. Mesmo as unidades do sistema métrico decimal, nada obstante sua base científica, apresentam as mesmas características, quando aplicadas à mensuração de um projeto ou de uma atividade. Basta raciocinar que construir $100 \mathrm{~km}$ de estrada de rodagem não representa sempre a mesma coisa em termos de engenharia, o que repercute no controle orçamentário. Com efeito, construir $100 \mathrm{~km}$ de estrada de rodagem nas montanhas de Minas Gerais leva um tempo, digamos t; os mesmos $100 \mathrm{~km}$ nas selvas amazônicas ou nos pantanais de Mato Grosso pode requerer um tempo $\mathbf{t}+\mathbf{n}$, mas R. Serv. Públ., Brasilia, 108 (1): jan/abr. 1973 
os mesmos $100 \mathrm{~km}$ em uma planície de terreno sedimentado pode requerer apenas um tempo $\mathbf{t}-\mathbf{n}$. Donde se vê que, em razão do orçamento-programa, as unidades de trabalho são sempre condicionadas ao tempo e às condições de trabalho, com decisivas influências no controle orçamentário. Ademais, não se deve confundir a aplicação das unidades de trabalho na mensuração de uma meta de um projeto ou de uma atividade com sua aplicação ao controle da eficiência do pessoal. Em outras palavras, o mesmo tipo de unidade pode servir a fins diversos, mas no que concerne ao orçamento-programa, quer se trate de operações tipicamente administrativas ou de execução de obras ou serviços, a unidade de trabalho deve ser simples, compreensível e, para o controle, correlacionada ao tempo. Também devemos ter em mente a possibilidade de mensuração indireta, através de relações das quais o cálculo percentual é o mais simples, como sugeria Armando Paiva, grande técnico de processamento eletrônico de dados do INPS, prematuramente falecido.

Tudo isto mostra que não se deve abandonar o sistema de mensuração e que este não é impraticável pelo simples motivo de que, aparentemente, o técnico poderá ficar indeciso na escolha da unidade de trabalho, para mensuração das operações tipicamente administrativas. Com efeito, a dificuldade de cotejar o trabalho de dois fiscais, como no exemplo acima, pode ser semelhante, em termos de orçamento-programa, à dificuldade em cotejar o trabalho de construção de estradas de rodagem em regiões diversas.

Voltemos, para exemplificar, à educação, face a sua simplicidade. Pode-se estabelecer a meta de $\mathbf{n}$ crianças que devam ser matriculadas em um ano letivo nas escolas administradas por um Departamento de Educação de certo Governo. Aluno se apresenta, pois, como unidade muito adequada para demonstrar a eficácia da ação do Governo no campo da educação, aulas exprimiria melhor o esforço do corpo docente. Enquanto a primeira mediria o resultado, esperado ou obtido, em um programa a segunda mediria o esforço desenvolvido na atividade. Mas, o Departamento de Educação produz uma série de trabalhos administrativos conducentes à efetivação da meta. Ora, em vez de procurar unidades específicas para medir o trabalho administrativo do Departamento, parece-nos que os técnicos de orçamento do Distrito Federal estão utilizando a mesma unidade, por exemplo, aluno, para medir também o trabalho administrativo, 
- que, aparentemente, se afigura de grande racionalidade, porque, sem sombra de dúvida, o trabalho administrativo está condicionado e é um auxiliar da função principal, que é prover ensino à população de certa faixa etária. ${ }^{22}$ Se no Brasil fosse possível ou desejável desenvolver estudos e pesquisas neste sentido, ter-se-ia, na presunção de resultados positivamente válidos, não só chegado a uma simplificação racional do sistema de mensuração, como se levaria à doutrina do orçamento-programa contribuição realmente valiosa.

\section{A PRATICA BRASILEIRA}

Concebido, destarte, o orçamento-programa, resta-nos tãosomente verificar como se apresenta, na prática brasileira, sua estrutura de contas representativas de programas, categorias econômicas e meios. Neste ponto parece-nos que se pode identificar um distanciamento da doutrina, tal como concebida na definição de Jesse Burkhead. Nós mesmos, no já citado Modelo de Orçamento-Programa para Municípios, demos mais ênfase à prática que à doutrina, pela simples razão de que nos pareceu mais seguro manter uma estrutura uniforme em todo o Brasil, que criar discrepâncias terminológicas em um modelo prático publicado por uma instituição que serve ao progresso administrativo dos Municípios e sob os auspícios do Ministério do Planejamento, responsável pela administração orçamentária do Governo Federal e espelho em que se miram Estados e Municípios, com justa razão aliás, pois cabe àquele Ministério, indiscutivelmente, a liderança em matéria de planejamento e orçamento no Brasil.

Observe-se, com efeito, a definição transcrita. Entre outras características, o orçamento-programa tem a de identificar os custos dos programas propostos para alcançar os objetivos. $\mathrm{Ne}$ cessariamente, a tarefa primária em orçamento-programa seria a de identificar os objetivos e quantificar as metas e, em seguida, formalizar os programas para realizar as metas e alcançar os objetivos. Um programa seria, então, um complexo de meios e ações, expressos monetariamente e perfeitamente delimitado no tempo, capaz de permitir à administração realizar as metas e alcançar os objetivos.

22. Veja-se sobre o assunto o Guia para o Sistema Integrado, de Planejamento, Progracios dos Ministérios da Fazendo do Canadá, publicado em portugués sob os auspiser consultado também com referéncianejamento, pela COCITEF. Este Guia pode

R. Serv. Públ., Brasília, 108 (1): jan/abr. 1973 
Tem havido, realmente, na prática certa confusão de conceito entre as palavras plano, programa e orçamento. Talvez por isto mesmo, o Prof. Frederick C. Mosher, da Syracuse University, na obra já citada, foi levado a dedicar quase todo o capítulo III a discutir o assunto. Planejar e programar uma ação não é, necessariamente, orçamentá-la, mas "o orçamento é aquele ingrediente do planejamento que disciplina o processo como um todo", na expressão do citado autor. ${ }^{23}$ A concepção filosófica de Mosher, portanto, é a de que o planejamento compreende a fixação de objetivos e a apresentação de cursos alternativos para a ação futura a fim de alcançar tais objetivos. Em segundo lugar, envolve a redução dessas alternativas de um número muito grande a uma quantidade menor $\mathrm{e}$, finalmente, chega-se ao curso de ação desejado e devidamente aprovado, o qual o autor consultado denomina de programa. ${ }^{24}$ Assim, Mosher confirma seu conceito anterior, emitido às páginas 18 , em que se assevera que "o processo orçamentário permanece um dos supremos exemplos de racionalidade no governo" (sic.: "The budget process remains one of the supreme exemples of rationality in government"), devido sobretudo ao sistema de classificação das transações governamentais que o orçamento desenvolve.

Quando se compreende o planejamento, a programação e o orçamento como processos integrados, fácil é, também, compreender que em economia e administração modernas não se planeja, programa e orçamenta, pela elementar razão de que vivemos em um mundo de recursos escassos, como geralmente se proclama. O propósito, o objetivo e a meta é que, em realidade, determinam a necessidade de planejamento, programação e orçamentação. Mesmo se os recursos fossem abundantíssimos, seria preciso cumprir a escala da trilogia acima, para condicionar os recursos certos ao objetivo exato no tempo oportuno, sem desperdício.

Desta maneira, é sempre o objetivo o determinante básico do processo de orçamentação, qualquer que seja o tipo de economia em que se viva.

23. Mosher, Frederick, C.: op. clt., pág. 49.

24. Sobre os mesmos termos em conceituação diversa, consulte-se: Campos, Roberto de Oliveira: Planejamento de Desenvolvimento Económico de Paises Subdesenvol. vidos (Caderno de Administraçăo Pública, n.० 2, Rio de Janeiro, Fundaçăo Getúlio Vargas, 1954). 
Chegamos aqui ao ponto crucial da discussão, por isto que o programa, na doutrina, parece não ter adquirido aquela noção que Mosher explana para, em seu lugar, tornar-se apenas uma projeção da estrutura de organização. Aliás, diga-se de passágem, nem tanto foi o citado Manual de Orçamento-Programa das Nações Unidas que contribuiu para estabelecer o programa como tal, isto é, categoria de classificação ligada à estrutura de organização mas, na verdade, a maioria dos divulgadores do referido Manual, especialmente em língua espanhola. ${ }^{25}$ Já se pode, no entanto, observar uma reversão neste processo, com as estruturas matriciais em que o objetivo dá as bases para o tipo de estrutura organizativa. Segundo este Manual, o programa deve expressar um produto final que, como vimos, seria quantificado como meta, representação por sua vez do objetivo a horizonte de um exercício financeiro. Deste modo. houve uma inversão: o objetivo, que deveria determinar o curso da ação, ou seja, o programa, passou a integrar o próprio conceito de programa. Aparentemente, não há divergência nos dois pontos de vista, por isto que, segundo o Manual das Nações Unidas, o programa deve expressar o produto final perseguido pela administração. Mas, talvez o modo como se redigiu a definição de programa, levou alguns países, como é o caso do Brasil, a basear toda a sua estrutura orçamentária independentemente do produto esperado, utilizando o programa, o subprograma, o projeto e a atividade como simples categorias de classificação, possivelmente estanques, tal como se utilizava antigamente pessoal, material de consumo, material permanente, serviços de terceiros e encargos diversos ou como se usa, com base na Lei $4.320 / 64$, as categorias econômicas. Na verdade, perdeu-se a noção de que o produto final esperado, ou seja, o objetivo quantificado em meta, é o cerne do orçamento-programa.

Este engano, possivelmente, estará internacionalizado, mas já começa a ser superado, a partir do chamado PPBS, ou, em português, SIPPO (veia-se a nota (4) da pág. 73), desenvolvido no Departamento de Defesa dos Estados Unidos, com MacNamara. O grande mérito do SIPPO (ou PPBS), pois, foi descobrir este engano e procurar colocar o processo orçamentário em seu devido lugar: fixação de objetivos (planejamento), determinação do curso de ação (programação) e, por fim, expressão financeira e quantitativa dessa programação: a orçamentação

25. ICAP: EI Presupuesto por Programas y Actividades (San José, Costa Rica, 1970). R. Serv. Públ., Brasilia, 108 (1): jan/abr. 1973 
como coroamento de todo o processo. Em outras palavras, primeiro identificar os problemas que afligem a administração ou sua clientela, estudá-los, clarificá-los, estudar as possíveis soluções, estabelecer cursos de ação e orçamentar os meios em função dos objetivos. Neste sentido é também a orientação dos trabalhos de planejamento, programação e orçamento dos Governos nacionais da França ${ }^{26}$ e do Canadá ${ }^{27}$

Por ora, porém, e até que se consolide a atual experiência brasileira de orçamento-programa, a nível federal, o programa permanecerá como mera categoria de classificação desdobrada, como já dissemos, em projeto e atividade. Parece mesmo que, pela segurança e prudência com que o Governo orienta sua ação, não é oportuno queimar uma etapa, tanto mais quanto a nível estadual e municipal, nem mesmo a concepção do programa como categoria de classificação está devidamente compreendida e assentada, pois, na verdade, muita vez, o programa confunde-se com a função, como é fácil de verificar pela análise de alguns orçamentos.

Nada obsta mesmo que a evolução se faça no sentido de fixação de objetivos e quantificação de metas, mantendo-se, porém, o programa, o projeto e a atividade como categorias básicas de classificação, o que parece ser mais simples, desde que, no entanto, não se confunda programa com função ou setor e a fixação de objetivos seja a preliminar determinante da elaboração do orçamento e dos planos. Nada impede, obviamente, o surgimento de outra estrutura orçamentária mais apropriada. Até lá, contudo, a tarefa básica é o, aperfeiçoamento constante do sistema que apresenta características bastante sadias.

Como o sistema orçamentário brasileiro evoluiu de uma classificação por elemento de despesas para categorias econômicas. com a Lei $4.320 / 64$, em conjunto com a classificação funcional, ainda que incipiente, e daí, a partir de 1965, para a classificação por programas, projetos e atividades, mantendo-se, necessariamente, as duas primeiras, alguns problemas conceituais surgiram no que tange às categorias de projeto e atividade. A adesão dos títulos, embora não aos conceitos, de despesas correntes e despesas de capital, foi relativamente rápida.

26. A Análise de Sistema na Racionalizaçăo do Orçamento, op. cit. (veja-se nota 15, pág. 43).

27. Guia para o Sistema Integrado de Planejamento, Programaçăo e Orçamento, op cit. (veja-se nota 21, pág. 53). 
A medida, porém, que se introduziu a nova terminologia, apareceu uma projeção, indevida contudo, de despesas correntes para atividade e de despesas de capital para projeto.

$\mathrm{Na}$ doutrina, como na prática, os dois pares de termos têm conceitos precisos e distintos. Com efeito, as despesas de capital transmitem a idéia de formação de bens de capital e as despesas correntes agrupam as dotações que, aparentemente. ao se monetarizarem, dissolvem-se na economia, sem agregação ao patrimônio de nenhuma instituição pública ou particular, com um círculo de vida relativamente curto. Por seu turno, o projeto e a atividade sintetizam conceitos de realizações, inerentes à definição do orçamento-programa.

Talvez, a escolha da palavra projeto não tenha sido das mais felizes, porque carrega consigo várias acepções, conforme a esteja empregando um profissional de engenharia, advocacia, economia, administração ou um legislador. Por isto, faz-se necessário conceituá-la com precisão no seu papel de categoria de classificação de transações governamentais, de modo que fique bem diferenciado da atividade.

A maior aproximação, ao que tudo indica, a que se chegou até agora foi dizer que o projeto, em orçamento-programa, "constitui um instrumento de ação sobre um conjunto de elementos que se combinam para obtenção de metas precisamente quantificadas, as quais realizadas normalmente não se repetem em outro exercício financeiro e permitem ou facilitam a execução, ou melhoria de execução, de uma ou mais atividades." ${ }^{28} \mathrm{~A}$ atividade seria "um instrumento de ação para o cumprimento de propósitos específicos e definidos, integrantes de um programa, envolvendo um conjunto de operações, tarefas ou trabalhos contínuos no tempo, associados ao objetivo de uma unidade administrativa, e que guardam entre si certo grau de homogenei-
dade." 29

Ora, como o projeto também é integrante de um programa, visa o cumprimento de propósitos específicos e definidos, envolve um conjunto de operações, tarefas ou trabalhos, associados ao objetivo de uma unidade administrativa, guardando certo grau de homogeneidade, a diferença entre projeto e atividade resta apenas na coordenada do tempo. Não, porém, um tempo

28. Modelo de Orçamento-Programa para Municipios, op. cit., pág. 23.
29. Modelo, op. cit., pág. 21 .

R. Sert. Públ, Brasilia, 108 (1): jan/abr. 1973 
orçamentário, mas um tempo histórico. Destarte, seria projeto todas aquelas operações governamentais cuja meta não se repete necessariamente a cada exercício, ao passo que à atividade está inerente a noção de continuidade. Dar aula é uma atividade porque a humanidade vem realizando esta tarefa desde os mais recônditos tempos da História, continuamente, e não pode deixar de fazê-lo. Tais operações são segregadas, apenas para efeito de orçamento, dentro de um tempo que nos toca como partícipe da operação. Na dura realidade, é através da atividade que o Governo realiza sua missão e, talvez, por isto é que muitos paises, como a França e o Canadá, nos documentos já citados, falem tão-só em um programa-atividade. Daí a vantagem primordial do orçamento-programa porque enfatiza a missão, o propósito, a meta, a atividade, a tarefa, algo em benefício à sociedade como um todo.

Em contraste, operações tais como a construção de um prédio escolar, ou a recepção a um lider nacional, são operações bloqueadas, necessárias em si mesmo, mas sem continuidade. A finalidade da primeira, por exemplo, a que o espirito do leitor poderá associar inúmeras outras, está em que aperfeiçoa ou cria condições para o surgimento de uma atividade. Pode-se construir outro prédio, fazer outra recepção, mas não existe continuidade entre uma operação e outra. Se fôssemos exprimir estes conceitos em linguagem algébrica, diríamos que a atividade é uma função contínua, ao passo que o projeto apresenta-se descontínuo em um ou vários pontos. Geometricamente, a representação da atividade seria por uma das figuras contínuas, como a reta, o círculo, a elípse. O conceito de projeto seria melhor representado por uma hipérbole ou, quiçá, por uma curva indicativa de um processo cíclico, mas não contínuo.

$\mathrm{Na}$ prática não seria melhor fundir os dois conceitos? Eis uma questão importante. Como já dissemos, o Guia já citado do Governo do Canadá apresenta apenas uma categoria, o programa-atividade. ${ }^{30}$ Parece, no entanto, que o treinamento levado a efeito a nivel estadual e municipal e a alta especialização dos técnicos do Ministério do Planejamento e Coordenação Geral poderão, pouco a pouco, dirimir todas as dúvidas neste campo e, assim, a estrutura orçamentária poderá, em um dia não muito longe, ficar plenamente consolidada com a terminologia perfeitamente esclarecida e que se adapte às circunstâncias da ambiência brasileira.

30. Op. cit., pág. 21 a 28 da traduçăo em português)

R. Serv. Públ., Brasília, 108 (1): jan/abr. 1973 
A estrutura programática se completa com as categorias econômicas às quais se apropriam os meios. Já examinamos alguns aspectos relativos às primeiras, mas, pelo menos um problema se apresenta ainda de relevância e diz respeito à reserva de contingência, que aparece classificada na estrutura do orçamento da União na categoria de transferência, embora, posteriormente no decurso da execução do orçamento, a própria União utilize tal reserva. A classificação adotada, pois, contraria frontalmente o conceito do $\S 2 .^{\circ}$ do artigo 12 já transcrito às páginas 80 . Não se configura, na realidade, transferência para nenhuma outra entidade de direito público ou privado. Por que, então, transferência? Na realidade, não faz sentido. Ao examinarmos a classificação econômica da amortização da dívida pública chegamos à conclusão de que se trata de conta sem incidência nas categorias econômicas (página 80 ). Em problemáticą idêntica acha-se a presente conta, cujo aparecimento no orçamento público já se fazia sentir desde alguns anos. Na verdade, a reserva de contingência pode aparecer como uma dotação global, como acontece atualmente ou em dotações específicas, elemento por elemento, projeto por projeto ou atividade por atividade.

Por outro lado, a reserva de contingência não se confunde com a reserva orçamentária, sendo esta última, uma parcela de cada dotação aprovada pelo Congresso, posta à parte e cuja liberação somente se fará no decorrer do exercício, em função do comportamento da receita e da necessidade real de sua utilização. A reserva orçamentária não cria problema de classificação.

Sugerimos que tanto a amortização da divida pública, por ser dotação para atender à baixa de passivo, e a reserva de contingência, por sua própria natureza, deixassem de ser apropriadas às categorias econômicas, pois, em qualquer uma delas sua classificação estará descaracterizada. Por outra, seria criar no plano de contas das categorias econômicas um título perfeitamente razoável, por exemplo, com a denominação de DESPESAS NÃO INCIDENTES EM CATEGORIAS ECONÔMICAS.

No que tange aos elementos de despesa, última parte da estrutura orçamentária, o orçamento-programa pressupõe um rol desses elementos, mas que sejam realmente elementos e não agregados de vários deles. Tem-se de ir ao átomo, quiçá ao próton e ao elétron e não ficar na molécula. Dizemos isto para 
chamar a atenção de que em planos de contas de muitos dos Governos brasileiros aparecem contas compostas como se fossem elementos de despesas. Para exemplificar, lembramo-nos perfeitamente de um título que vem a calhar: homenagens e recepções. Ora, tal conta não é um elemento, mas um conjunto de despesas que vão possibilitar a homenagem e a recepção. $\mathrm{Na}$ técnica do orçamento-programa homenagens e recepções integrariam um projeto, por suas características já descritas. Tudo leva, portanto, a sobrelevar a necessidade de realizar uma revisão dos planos de contas a fim de que se proceda à simplificação e homogeneização dos mesmos, adaptados, convenientemente, à doutrina e à prática do orçamento-programa.

Substancialmente, o presente trabalho dedicou-se, inclusive pelos motivos expostos na parte introdutória, ao estudo da despesa pública em seu aspecto de orçamento-programa, nem poderia deixar de ser de outro modo, embora qualquer estudioso do assunto esteja seguramente advertido da importância da receita como instrumento de captação de recursos financeiros. 


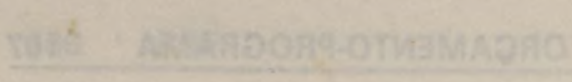

